\title{
PENGEMBANGAN PERANGKAT PEMBELAJARAN IPA DENGAN MODEL PROBLEM BASED LEARNING BERBASIS OUTDOOR LEARNING
}

\section{DEVELOPING SCIENCE LEARNING DEVICE USING PROBLEM BASED LEARNING MODEL BASED ON OUTDOOR LEARNING} Dwi Supriyantoro $^{1 *}$, Meini Sondang Sumbawati ${ }^{2}$, Nurmida Catherine Sitompul ${ }^{2}$

\author{
${ }^{1}$ Program Studi Pascasarjana Teknologi Pendidikan Universitas PGRI Adi Buana Surabaya \\ ${ }^{2}$ Pendidikan Vokasi Pascasarjana Universitas Negeri Surabaya \\ ${ }^{3}$ Program Studi Pascasarjana Teknologi Pendidikan Universitas PGRI Adi Buana Surabaya \\ *Email:dwisupriyantoro@gmail.com
}

Diterima: 14 April 2019. Disetujui: 20 April 2019. Dipublikasikan: 31 Juli 2019

\begin{abstract}
Abstrak. Pengembangan perangkat pembelajaran adalah salah satu upaya mengatasi permasalahan belajar. Berdasarkan pengalaman dan pengamatan di sekolah khususnya di Sekolah Menengah Pertama pada akhir-akhir ini banyak yang menyelenggarakan kegiatan belajar di luar kelas atau yang lebih dikenal dengan Outdoor Learning. Kenyataan di lapangan ternyata banyak sekolah penyelenggara yang mengadakan kegiatan Outdoor Learning belum menggunakan perangkat pembelajaran yang mendukung dan identik dengan pembelajaran di luar kelas. Seperangkat pembelajaran yang dirancang khusus untuk keperluan proses pembelajaran. Perangkat pembelajaran ini berupa produk silabus, Rencana Pelaksanaan Pembelajaran (RPP), bahan ajar, dan Lembar Kerja Peserta Didik (LKPD), diharapkan dapat memenuhi kebutuhan belajar peserta didik, membantu guru sebagai fasilitator dan lebih mengoptimalkan pembelajaran. Hasil penilaian ahli isi mata pelajaran terhadap perangkat pembelajaran rerata berkualifikasi sangat baik, hasil penilaian ahli desain terhadap perangkat pembelajaran rerata dalam kualifikasi sangat baik, hasil uji coba perorangan terdapat koreksi diantaranya: 21 kesalahan pengetikan, 7 kesalahan penggunaan tanda baca, 6 kesalahan penulisan huruf kapital dan huruf kecil, dan 2 pemakaian kata yang sulit dipahami. Telah dilakukan upaya revisi berdasarkan hasil koreksi tersebut. Hasil uji lapangan peserta didik kualifikasi baik dan respon positif peserta didik $82 \%$ kategori baik, hasil penilaian dan tanggapan guru mata pelajaran kualifikasi sangat baik. Hasil antara pretes dan postes menggunakan derajat kebebasan 29 dan taraf signifikansi 0,05 ,diperoleh melalui uji-t taraf korelasi data pretes dan pos tes 0,547 dan tingkat signifikansi 0,001 dan uji $\mathrm{t}=-6,733$, df $=35$. Nilai signifikasi $0,001<0,05$; maka terdapat perbedaan signifikan antara hasil pretes dan posttes dan nilai signifikasi (2-tailed) $=0,000$. Terdapat perbedaan mean yang signifikan antara pretes dan posttes siswa kelas VIII B sebelum dan sesudah menggunakan perangkat pembelajaran IPA model PBL berbasis outdoor learning. Hal ini menunjukkan perangkat pembelajaran IPA model PBL berbasis outdoor learning efektif untuk digunakan.
\end{abstract}

Kata Kunci: perangkat pembelajaran, pembelajaran IPA, model problem based learning, outdoor learning

Abstract. Development of learning materials is one of the efforts to overcome learning problems. Based on experience and observations in schools, especially in junior high school, lately, many have held outdoor learning activities. However, there are still many schools that organize outdoor learning that have not used learning materials that support outdoor learning. This study aims to develop a set of teaching materials specifically designed for the needs of the learning process. The learning tools are syllabus, lesson plans, teaching materials, and student worksheets. This tool is expected to accommodate the learning interests of students and help teachers as facilitators in optimizing the learning process. Content expert assessment toward learning device is very good qualification, expert assessment design toward learning device is very good qualification, student trial assessment there are some corrections: 21 misstyped, 7 wrong mark, 6 wrong capital writing, and 2 difficult word. Revision efforts have been made based on the results of the correction. The results of field tests on the responses of well-qualified students and positive responses of students were $82 \%$ in good category, the results of the assessment and responses of qualified subject teachers were very good. Pretest and posttest result use 29 free style and signify 0.05 are got through the T-test. Data correlation of pretest and posttest 0.547 and signification value is 0.001 and $\mathrm{T}$-test $=-6.733, \mathrm{df}=35$. Significant value $0.001<0.05$. There is a difference between the pre test and post test value and significant value $(2$-tailed) $=0,000$. There is a significant difference in mean between the pretest and posttes of students before and after using a problem-based learning model for science learning materials for outdoor learning. In conclusion, science learning devices based on PBL models for outdoor learning are effective to be implemented.

Keywords: Learning device, Science Learning, Problem Based Learning Model, Outdoor Learning Activity. 


\section{PENDAHULUAN}

Pembelajaran IPA memiliki potensi yang sangat besar dalam upaya membangun bangsa, namun ternyata selama ini hanya dianggap beban berat yang kurang disenangi oleh peserta didik. Hanya sedikit peserta didik yang berminat untuk belajar IPA, sehingga hal ini mengakibatkan kualitas pendidikan IPA menjadi rendah. Fakta rendahnya kualitas pendidikan menuntut pemerintah untuk melakukan pembaharuan dalam sistem pendidikan. Salah satunya yaitu dikeluarkannya kurikulum 2013 sebagai dasar dalam pelaksanaan proses pendidikan di Indonesia.

Kurikulum 2013 yang dikembangkan dengan berbasis kompetensi sangat diperlukan sebagai instrumen untuk mengarahkan peserta didik menjadi: (1) manusia berkualitas yang mampu dan proaktif menjawab tantangan zaman yang selalu berubah; (2) manusia terdidik yang beriman dan bertaqwa kepada Tuhan Yang Maha Esa, berakhlak mulia, sehat, berilmu, cakap, kreatif, mandiri; dan (3) warga negara yang demokrasi, bertanggung jawab [1]. Keterlaksanaan kurikulum 2013 berjalan dengan baik apabila proses pembelajarannya selalu mengintegrasikan domain sikap atau afektif, kognitif dan psikomotor. IPA memiliki dimensi sikap ilmiah (scientific attitude), proses ilmiah (scientific process), dan produk ilmiah (scientific product), berupa pengetahuan [2, 3]. Oleh karena itu, keberhasilan keterlaksanaan kurikulum 2013 tidak hanya dipengaruhi oleh proses pembelajaran yang menuntut guru untuk selalu kreatif dalam mengembangkan metode yang digunakan tetapi tersedianya perangkat pembelajaran juga penting dalam menunjang proses pembelajaran IPA. Akan tetapi, fakta di lapangan menunjukkan bahwa ketersediaan bahan ajar seperti LKPD dan contoh instrumen penilaian masih kurang lengkap.

Berdasarkan fenomena tersebut maka dalam pembelajaran IPA masih diperlukan adanya suatu perangkat pembelajaran IPA yang dapat menunjang pelaksanaan proses pembelajarannya, khususnya dalam melaksanakan scientific approach[4,5]. Chodijah et al [6] menyatakan bahwa perangkat pembelajaran merupakan segala alat dan bahan yang digunakan guru untuk melakukan proses pembelajaran. Model Problem-based Learning $(P B L)$ merupakan salah satu model pembelajaran yang direkomendasikan di dalam kurikulum 2013 sebagai salah satu model pembelajaran yang inovatif [7-10].

Dengan melibatkan lingkungan sekitar, diharapkan peserta didik dengan mudah menguasai konsep IPA karena siswa melakukan pengamatan pada situasi yang konkrit. Dampak positif dari pendekatan lingkungan yaitu peserta didik terpacu sikap rasa keingintahuannya tentang sesuatu yang ada di lingkungannya. Peserta didik akan merasa lebih tertantang karena berhadapan langsung dengan obyek nyata. Perangkat pembelajaran IPA kelas VIII di SMPN 2 Tanggulangin masih terbatas memanfaatkan fasilitas yang ada di sekolah yakni hanya bergantung pada sumber buku teks, peralatan laboratorium maupun media elektronik.

Dari masalah tersebut, perlu dilakukan pengembangan perangkat pembelajaran yang dirancang khusus (by design) untuk pembelajaran IPA di kelas VIII, dengan harapan pengembangan perangkat pembelajaran IPA model Problem Based Learning (PBL) berbasis outdoor learning sebagai upaya untuk mencapai tujuan-tujuan pembelajaran IPA.Pengembangan Perangkat Pembelajaran IPA dengan Model Problem Based Learning (PBL) Berbasis Outdoor Learning di kelas VIII semester 1 SMPN 2 Tanggulangin bertujuan menghasilkan seperangkat pembelajaran berbasis outdoor learning yang dapat membantu pebelajar untuk memperoleh dan mengembangkan pengetahuan dan keterampilan mengajar IPA secara efektif dalam mencapai tujuan pembelajaran.

\section{METODE PENGEMBANGAN}

Dalam penelitian ini, metode yang digunakan adalah metode penelitian dan pengembangan. "Metode penelitian dan pengembangan atau dalam bahasa Inggrisnya Research and Development.

Model pengembangan yang digunakan yaitu model pengembangan menurut Borg \&Gall, menyebutkan bahwa terdapat 10 tahapan dalam penelitian dan pengembangan yaitu: (1) mengumpulkan informasi dan penelitian pendahuluan; (2) melakukan perencanaan penelitian; (3) mengembangkan bentuk produk awal; (4) melakukan uji coba terbatas produk awal untuk menghasilkan produk utama (Preliminary field test); (5) melakukan revisi terhadap produk utama; (6) melakukan uji coba produk utama (Main field test); (7) melakukan revisi terhadap produk utama untuk menghasilkan produk final; (8) melakukan uji coba lapangan produk final (operational field test); (9) melakukan revisi terhadap produk final; (10) mendiseminasi dan mengimplementasikan produk [11]

Prosedur pengembangan dalam pengembangan perangkat pembelajaran IPA disini terdiri dari 6 tahap. Tahap I: Pengumpulan informasi dilakukan dengan melakukan studi pendahuluan yang meliputi studi pustaka dan survei lapangan. Tahap II: Desain produk dilaksanakan dengan melakukan perencanaan dan pengembangan perangkat pembelajaran.Tahap III: Tahap validasi dimana desain produk perangkat pembelajaran IPA. Tahap IV: Tahap uji coba dan revisi produk merupakan tahap dimana produk yang dihasilkan dapat di uji coba setelah melalui beberapa revisi. Tahap V: Tahap produk akhir pada perangkat pembelajaran yang digunakan sebagai paduan pembelajaran IPA dengan model Problem Based 
Learning (PBL) berbasis Outdoor Learning. Tahap VI: Tahap diseminasi merupakan tahap akhir dari suatu penelitian pengembangan yang telah menghasilkan produk akhir [12]

Produk yang dikembangkan meliputi perangkat pembelajaran IPA berbasis Problem Based Learning (PBL) Berbasis Outdoor Learning yang terdiri dari a) Silabus Pengembangan b) Rencana Pelaksanaan Pembelajaran, c) Bahan Ajar, dan d) Lembar Kerja Peserta Didik (LKPD).Instrumen yang digunakan untuk pengumpulan data berupa angket dan tes. Angket dipakai untuk mengumpulkan data hasil penilaian dan tanggapan dari ahli isi mata pelajaran, ahli desain dan media pembelajaran, data dari peserta didik saat melakukan uji coba perorangan, uji coba kelompok kecil dan uji coba lapangan. Data pre tes digunakan untuk mengetahui hasil belajar peserta didik sebelum menggunakan pengembangan perangkat pembelajaran dan post tes diberikan pada peserta didik setelah menggunakan produk pengembangan perangkat pembelajaran. [13-16]

\section{Uji Coba Produk}

Desain Uji Coba untuk mengetahui tingkat keefektifan dan kelayakan produk perangkat pembelajaran dilakukan beberapa rangkaian uji coba terhadap produk tersebut lalu dilakukan revisi. Produk pengembangan yang dihasilkan akan dicobakan melalui beberapa tahap yakni: (a) Tinjauan oleh ahli isi mata pelajaran.Bertujuan agar mendapatkan data penilaian, tanggapan berupa komentar atau saran terhadap ketepatan isi perangkat pembelajaran yang di dalamnya terdapat silabus, Rencana Pelaksanaan Pembelajaran (RPP), bahan ajar, dan Lembar Kerja Peserta Didik (LKPD), (b) Tinjauan oleh ahli media. Tujuannya untuk mendapatkan data penilaian, komentar atau saran mengenai kesesuain media perangkat pembelajaran yang dibuat dalam bahan silabus, Rencana Pelaksanaan Pembelajaran (RPP), bahan ajar, dan Lembar Kerja Peserta Didik (LKPD). (c) Tinjauan oleh ahli desain. Bertujuan untuk mendapatkan data penilaian, komentar atau saran mengenai ketepatan desain perangkat pembelajaran yang berisi silabus, RPP, bahan ajar, dan LKPD.

(d). Uji coba perorangan. Penilaian formatif tahap awal dilakukan secara orang per orang bertujuan untuk mengetahui dan menghilangkan kesalahan-kesalahan yang terdapat dalam pembelajaran, dan untuk memperoleh tanggapan awal tentang isi produk perangkat pembelajaran dari peserta didik. Dilakukan dengan cara berinteraksi antara perancang dengan peserta didik secara perseorangan. Dalam tahap ini, perancang mengambil tiga peserta didik sebagai wakil dari populasi kelas sasaran. Tes produk digunakan pada penilaian tahapan ini dengan melibatkan peserta didik. Ketika peserta didik mengamati produk tersebut diharapkan dapat menemukan kesalahan pengetikan ketik, kesalahan cetak, bagian isi yang terbuang atau hilang, halaman yang terlewatkan atau kosong, tabel atau grafik yang kurang jelas. Kemudian peserta didik dapat menuliskan catatan komentar dan saran pada bagian lembar respon yang disediakan oleh perancang. (e) Uji coba kelompok kecil. Uji coba ini dimaksudkan untuk menentukan keefektifan perubahan yang telah dibuat pada produk pengembangan berdasarkan hasil uji perseorangan sehingga dapat diketahui masalah belajar yang mungkin dialami peserta didik. Maksud lain digunakannya uji coba ini adalah untuk menentukan apakah peserta didik menggunakan produk pengembangan itu tanpa interaksi dengan guru. Prosedur yang digunakan penilaian kelompok kecil yaitu dengan penilai (guru) memulai dengan menjelaskan bahwa produk perangkat pembelajaran masih dalam pembentukan dari usaha pengembangan dan mengharapkan masukan, saran, cara-cara demi perbaikan produk tersebut. Dalam proses pelaksanaannya ikut campur gurudiminimalisasi agar lebih obyektif.Pelaksanaan uji coba kelompok kecil ini berupa angket sikap, lalu hasilnya dirangkum dan dapat dibuat untuk keputusan dalam perbaikan atau revisi produk perangkat pembelajaran. (f) Uji coba lapangan[14]

Pada tahap penilaian formatif, guru berusaha menciptakan suasana belajar yang menyerupai dengan situasi yang dikehendaki berkaitan dengan penggunaan produk pembelajaran yang dikembangkan. Tujuan tahap akhir penilaian formatif ini adalah menentukan apakah revisi yang telah dibuat berdasarkan hasil dari tahap uji kelompok kecil sudah efektif dan apakah pembelajaran dapat dilaksanakan dalam lingkungan seperti yang dimaksudkan. Untuk bisa menjawab pertanyaan ini, maka semua bahan yang terdiri dari silabus, RPP, bahan ajar dan LKPD, haruslah direvisi dan siap dijalankan[17]

\section{HASIL PENGEMBANGAN}

\section{Analisis Data Perangkat Pembelajaran}

Hasil penilaian/tanggapan dari ahli desain pembelajaran terhadap perangkat pembelajaran dapat dilihat pada Tabel 1. Persentase penilaian desain perangkat pembelajaran secara keseluruhan diperoleh rata-rata $=85 \%$. Setelah angka persentase tingkat ketercapaian perangkat pembelajaran85\% dikonversikan pada tabel kelayakan, maka menunjukkan bahwa perangkat pembelajaran dalam kualitas sangat baik.

Tabel 1. Hasil penilaian/tanggapan ahli desain

\begin{tabular}{clc}
\hline No & Desain Pembelajaran & $\begin{array}{c}\text { Jumlah skor } \\
\text { dalam \% }\end{array}$ \\
\hline 1 & Ukuran fisik & $90 \%$ \\
2 & Desain kulit & $84 \%$ \\
3 & Pemilihan huruf & $80 \%$ \\
4 & Tata letak & $84 \%$ \\
5 & Tipografi & $80 \%$
\end{tabular}




\begin{tabular}{|c|c|}
\hline Ilustrasi isi & $90 \%$ \\
\hline Rata-rata & $85 \%$ \\
\hline
\end{tabular}

\section{Analisis Data Perangkat Pembelajaran}

Hasil penilaian/tanggapan dari ahli media pembelajaran terhadap perangkat pembelajaran dapat dilihat pada Tabel 2.

Tabel 2. Hasil penilaian/tanggapan ahli media pembelajaran

\begin{tabular}{clc}
\hline No & \multicolumn{1}{c}{ Desain Pembelajaran } & $\begin{array}{c}\text { Jumlah skor } \\
\text { dalam \% }\end{array}$ \\
\hline 1 & $\begin{array}{l}\text { Ketepatan ilustrasi pada cover } \\
\text { perangkat }\end{array}$ & $80 \%$ \\
2 & Kesesuaian materi dengan & $100 \%$ \\
3 & media & $100 \%$ \\
4 & Kualitas kertas & $100 \%$ \\
5 & Ukuran huruf & $80 \%$ \\
6 & Kenempatan gambar & $80 \%$ \\
7 & Pengorganisasian desain pesan & $80 \%$ \\
\hline \multicolumn{2}{c}{ Rata-rata } & $88,57 \%$ \\
\hline
\end{tabular}

Maka persentase penilaian ahli media terhadap perangkat pembelajaran secara keseluruhan $88,57 \%$. Setelah angka persentase tingkat ketercapaian perangkat pembelajaran $88,57 \%$ dikonversikan pada tabel kelayakan, maka menunjukkan bahwa perangkat pembelajaran dalam kualitas sangat baik.

\section{Analisis Data Tanggapan/Respon Peserta Didik.}

Hasil analisis data tanggapan peserta didik terhadap bahan ajar dapat dilihat pada Tabel 3 .

\section{Analisis Data Hasil Uji Coba Kelompok Kecil}

Hasil uji kelompok kecil terhadap kelayakan Lembar Kerja Peserta Didik (LKPD) dapat dilihat pada Tabel 4. Rerata persentase $84 \%$ apabila dikonversikan dengan tabel kelayakan bisa dikatakan bahwa bahan ajar dalam kualifikasi baik. Tapi meskipun pada kualifikasi baik, tetap memperhatikan saran dari peserta didik demi penyempurnaan produk bahan ajar.Rerata persentase $84 \%$ apabila dikonversikan dengan tabel kelayakan bisa dikatakan bahwa LKPD dalam kualifikasi baik. Tapi meskipun pada kualifikasi baik, tetap memperhatikan saran dari peserta didik demi penyempurnaan produk LKPD.

Tabel 3. Hasil penilaian/tanggapan bahan ajar uji kelompok kecil

\begin{tabular}{clc}
\hline No & Komponen bahan ajar & $\begin{array}{c}\text { Jumlah skor } \\
\text { dalam \% }\end{array}$ \\
\hline 1 & Penampilan bahan ajar & $93 \%$ \\
2 & Kerangka isi & $87 \%$ \\
3 & Kejelasan petunjuk & $83 \%$ \\
4 & Ukuran dan jenis huruf & $90 \%$ \\
5 & Paparan materi sesuai & $83 \%$
\end{tabular}

tujuan

\begin{tabular}{clc}
6 & Sistematika materi & $87 \%$ \\
7 & Gambar sesuai materi & $87 \%$ \\
8 & Gambar dapat dipahami & $87 \%$ \\
9 & Tugas dan latihan & $77 \%$ \\
10 & Rangkuman materi & $70 \%$ \\
11 & Uji kompetensi & $80 \%$ \\
12 & Penyajian materi & $87 \%$ \\
13 & Materi dapat dipahami & $83 \%$ \\
14 & Memotivasi peserta didik & $87 \%$ \\
\hline \multicolumn{2}{c}{ Rata-rata } & $84 \%$ \\
\hline
\end{tabular}

Tabel 4. Hasil penilaian/tanggapan LKPD uji kelompok kecil

\begin{tabular}{clc}
\hline No & \multicolumn{1}{c}{ Komponen LKPD } & $\begin{array}{c}\text { Jumlah skor } \\
\text { dalam \% }\end{array}$ \\
\hline 1 & Penampilan LKPD & $90 \%$ \\
2 & Kerangka isi & $87 \%$ \\
3 & Kejelasan petunjuk & $87 \%$ \\
4 & Ukuran dan jenis huruf & $83 \%$ \\
5 & Paparan materi sesuai & $87 \%$ \\
6 & tujuan & $80 \%$ \\
7 & Gistematika materi & $83 \%$ \\
8 & Gambar sesuai materi & $80 \%$ \\
9 & Tugas dan latihan & $83 \%$ \\
10 & Rangkuman materi & $67 \%$ \\
11 & Uji kompetensi & $87 \%$ \\
12 & Penyajian materi & $87 \%$ \\
13 & Materi dapat dipahami & $90 \%$ \\
14 & Memotivasi peserta didik & $83 \%$ \\
\hline \multicolumn{2}{c}{ Rata-rata } & $84 \%$ \\
\hline
\end{tabular}

Hasil angket tanggapan peserta didik pada uji lapangan terhadap perangkat pembelajaran telah dianalisis dan disajikan pada Tabel 5.

Rerata persentase tanggapan peserta didik terhadap bahan ajar dan LKPDsebesar $84 \%$. Rerata $84 \%$ jika dikonversikan pada tabel kelayakan, maka berada pada kualifikasi baik. Meskipun perangkat pembelajaran bahan ajar dan LKPD berada pada kualfikasi baik, tetap dilakukan penyempurnaan memakai saran/komentar dari peserta didik.

Tabel 5. Hasil penilaian/tanggapan uji lapangan terhadap perangkat pembelajaran

\begin{tabular}{clc}
\hline No & \multicolumn{1}{c}{ Komponen } & $\begin{array}{c}\text { Jumlah skor } \\
\text { dalam \% }\end{array}$ \\
\hline 1 & Penampilan fisik & $88 \%$ \\
2 & Kerangka isi & $83 \%$ \\
3 & Kejelasan petunjuk & $77 \%$ \\
4 & Ukuran dan jenis huruf & $91 \%$ \\
5 & Paparan materi sesuai & $84 \%$ \\
6 & tujuan & $79 \%$
\end{tabular}


7 Gambar sesuai materi $\quad 88 \%$

8 Gambar dapat dipahami $\quad 86 \%$

9 Tugas dan latihan $\quad 81 \%$

10 Rangkuman materi $80 \%$

11 Uji kompetensi $86 \%$

12 Penyajian materi $79 \%$

13 Materi dapat dipahami $89 \%$

14 Memotivasi peserta didik $\quad 88 \%$

Rata-rata $84 \%$

\section{Analisis Data Hasil Penilaian/Tanggapan Guru}

Penilaian/tanggapan guru mata pelajaran tentang perangkat pembelajaran silabus memperoleh rerata persentase sebesar 94\%. Jika dikonversikan pada tabel kelayakan $94 \%$ berada pada kualifikasi sangat baik. Meskipun pada kualifikasi sangat baik, tetap dilakukan perbaikan silabus berdasarkan masukan dan saran dari guru mata pelajaran. Penilaian/tanggapan guru mata pelajaran tentang perangkat pembelajaran RPP rerata persentase sebesar $90 \%$. Jika dikonversikan pada tabel kelayakan $90 \%$ berada pada kualifikasi sangat baik. Meskipun pada kualifikasi sangat baik, tetap dilakukan perbaikan RPP berdasarkan masukan dan saran dari guru mata pelajaran.

Penilaian/tanggapan guru tentang perangkat pembelajaran bahan ajar dapat dihitung rerata persentase sebesar $85 \%$. Jika dikonversikan pada tabel kelayakan $85 \%$ berada pada kualifikasi sangat baik. Meskipun pada kualifikasi sangat baik, tetap dilakukan perbaikan bahan ajar berdasarkan masukan dan saran dari guru mata pelajaran. Penilaian/tanggapan guru tentang perangkat pembelajaran LKPD rerata persentase sebesar 95\%. Jika dikonversikan pada tabel kelayakan $95 \%$ berada pada kualifikasi sangat baik. Meskipun pada kualifikasi sangat baik, tetap dilakukan perbaikan LKPD berdasarkan masukan dan saran dari guru mata pelajaran.

\section{Uji Efektivitas perangkat pembelajaran}

Untuk uji efektivitas perangkat pembelajaran, maka dilakukan uji $t$ dengan prasyarat uji normalitas dan uji homogenitas.Uji normalitas dilakukan sebelum data diolah berdasarkan metode-metode penelitian yang diajukan. Uji normalitas data bertujuan untuk mendeteksi distribusi data dalam satu variabel yang akan digunakan dalam penelitian. Uji homogenitas digunakan untuk mengetahui apakah beberapa varian populasi adalah sama atau tidak. Uji ini dilakukan sebagai prasyarat dalam analisis independent sampel $\mathrm{t}$ test. Asumsi yang mendasari dalam analisis varian adalah bahwa varian dari populasi adalah sama.

\section{Uji normalitas}

Uji normalitas data dimaksudkan untuk memperlihatkan bahwa data sampel berasal dari populasi yang berdistribusi normal. Adapun yang diuji normalitasnya adalah hasil pre tes dan pos tes dari model konvensional dan model PBL. Uji normalitas yang digunakan adalah uji KolmogorovSmirnov menggunakan SPSS 20

Paired Samples Statistics

\begin{tabular}{llrrrr} 
& & Mean & N & Std. Dev & Std. Error \\
\hline Pair & Pre Tes & 60,56 & 36 & 16,978 & 2,830 \\
1 & Pos & 76,53 & 36 & 8,521 & 1,420
\end{tabular}

Tabel 6. Uji normalitas

Descriptive Statistics

\begin{tabular}{lrrrrr} 
& N & Mean & Std. & Min & Max \\
\hline Pre tes & 36 & 60,56 & 16,978 & 30 & 85 \\
Pos Tes & 36 & 76,53 & 8,521 & 55 & 95 \\
\hline
\end{tabular}

Tabel 7. One sample Kolmogorov-Smirnov Test

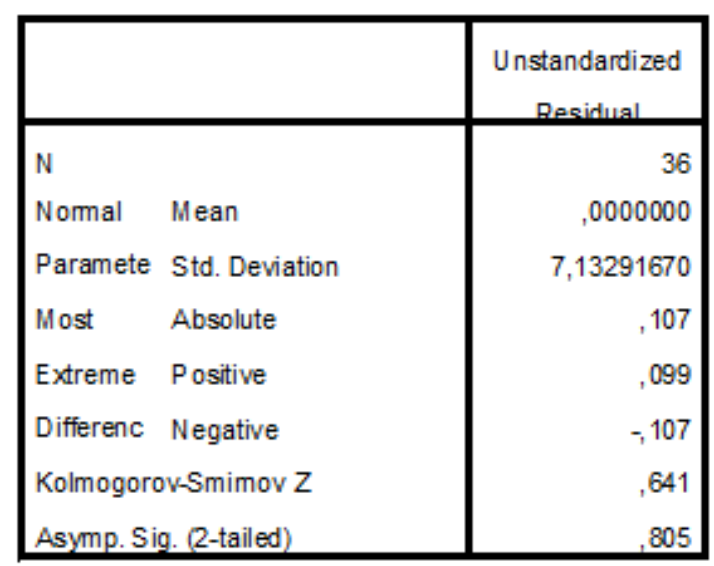

a. Test distribution is Normal.

b. Calculated from data.

Berdasarkan hasil uji normalitas diketahui nilai signifikansi $0,805>0,05$, maka dikatakan bahwa nilai residual berdistrbusi normal.

\section{Uji homogenitas}

Dimaksudkan untuk memperlihatkan bahwa dua kelompok data sampel berasal dari populasi yang memiliki variansi yang sama Adapun yang diuji homogenitasnya adalah hasil pre tes dan post tes dari model konvensional dan model PBL. Diperoleh hasil signifikansi perbedaan nilai pre tes dan pos tes $0,112>0,05$ berarti variansi setiap sampel sama atau homogen. 
Tabel 8. Uji homogenitas

ANOVA

Perbedaan Nilai

\begin{tabular}{cccccc}
\hline & Sum of & & Mean & & \\
& Squares & df & Square & F & Sig. \\
\hline Between & 3218,889 & 7 & 459,841 & 1,874 &, 112 \\
Groups & & & & & \\
Within & 6870,000 & 28 & 245,357 & & \\
Groups & & & & & \\
Total & 10088,88 & 35 & & \\
\hline
\end{tabular}

Tabel 9. Uji-T korelasi Pre Tes dan Pos Tes

Paired Samples Correlations

\begin{tabular}{|c|c|c|c|c|}
\hline & & $\mathrm{N}$ & Correlation & Sig. \\
\hline Pair 1 & $\begin{array}{c}\text { Pre Tes \& Pos } \\
\text { Tes }\end{array}$ & 36 & ,547 & ,001 \\
\hline
\end{tabular}

Paired Samples Test

\begin{tabular}{|c|c|c|c|c|c|c|c|c|}
\hline & \multicolumn{5}{|c|}{ Paired Differences } & \multirow{3}{*}{$\mathrm{T}$} & \multirow{3}{*}{$\mathrm{df}$} & \multirow{3}{*}{$\begin{array}{l}\text { Sig.(2- } \\
\text { tailed) }\end{array}$} \\
\hline & \multirow[b]{2}{*}{ Mean } & \multirow{2}{*}{$\begin{array}{c}\text { Std. } \\
\text { Deviation }\end{array}$} & \multirow{2}{*}{$\begin{array}{l}\text { Std. } \\
\text { Error } \\
\text { Mean }\end{array}$} & \multicolumn{2}{|c|}{$\begin{array}{l}\text { 95\% Confidence } \\
\text { Interval of the } \\
\text { Difference }\end{array}$} & & & \\
\hline & & & & Lower & Upper & & & \\
\hline $\begin{array}{c}\text { Pair1 Pre } \\
\text { Tes-Pos Tes }\end{array}$ & $-15,972$ & 14,234 & 2,372 & $-20,788$ & $-11,156$ & $-6,733$ & 35 &, 000 \\
\hline
\end{tabular}

Taraf korelasi data pretes dan pos tes 0,547 dan tingkat signifikansi 0,001 dan uji $\mathrm{t}=-6,733$, df $=35$. Nilai signifikasi $0,001<0,05$; maka terdapat perbedaan signifikan antara hasil pre tes dan pos tes. Dan nilai signifikasi (2-tailed) $=0,000$ sehingga untuk hipotesis h0 ditolak dan h1 diterima. Artinya terdapat perbedaan mean yang signifikan antara pre tes dan post tes siswa kelas VIII B SMPN 2 Tanggulangin, sebelum dan sesudah menggunakan perangkat pembelajaran IPA model PBL berbasis outdoor learning.

\section{KESIMPULAN}

Setelah melalui beberapa uji produk yakni uji ahli mata pelajaran, ,ahli desain dan media pembelajaran, uji coba perorangan, uji coba kelompok kecil, serta uji coba lapangan dapat disimpulkan bahwa pengembangan perangkat pembelajaran IPA dengan model Problem Based Learning (PBL) berbasis outdoor learning di kelas VIII SMP Negeri 2 Tanggulangin Sidoarjo sudah layak untuk digunakan. Perangkat pembelajaran IPA berupa silabus, RPP, bahan ajar dan LKPD yang dikembangkan dengan model PBL berbasis outdoor learning layak digunakansetelah diuji kelayakan. Uji Ahli Mata Pelajaran: (1) Dosen Pendidikan MIPA penilaian perangkat pembelajaran rerata persentasenyasebesar $88,25 \%$ (2) Guru mata pelajaran yaitu Guru IPA SMP Negeri 2 Tanggulangindiperoleh data rerata persentasenya seebsar 91\%, dan dikonversikan pada skala penilaian kelayakan produk berada pada skala sangat baik. Penilaian ahli desain pembelajaran sebesar $85 \%$, jika dikonversikan pada tabel kelayakan menunjukkan desain perangkat pembelajaran berada pada skala sangat baik.Hasil angket penilaian/tanggapan uji kelompok kecil diperoleh rerata persentase penilaian perangkat pembelajaran bahan ajar dan LKPD sebesar $84 \%$, apabila dikonversikan pada tabel kelayakan menunjukkan desain perangkat pembelajaran berada pada skala baik. Selanjutnya, hasil angket penilaian/tanggapan uji coba lapangan diperoleh rerata persentase tanggapan peserta didik terhadap bahan ajar dan LKPD sebesar 84\%, jika dikonversikan pada tabel kelayakan berada pada kualifikasi baik.Persentase respon positif peserta didik terhadap perangkat pembelajaran bahan ajar dan LKPD sebesar $82 \%$.

\section{DAFTAR PUSTAKA}

[1] Sila, I. M. (2014). Rasinalisasi pengembangan kurikulum dan penyempurnaan pola pikir pembelajaran. Widya Accarya, 3(1).

[2] Zainuddin, H. M. (2015). Implementasi kurikulum 2013 dalam membentuk karakter anak bangsa. UNIVERSUM: Jurnal KeIslaman dan Kebudayaan, 9(1). 
[3] Harosid, H. A. R. U. N. (2017). Kurikulum 2013 Revisi 2017. Kementerian Pendidikan Nasional Republik Indonesia.

[4] Priscylio, G., \& Anwar, S. (2019). Integrasi Bahan Ajar IPA Menggunakan Model Robin Fogarty Untuk Proses Pembelajaran IPA di SMP. Jurnal Pijar Mipa, 14(1), 1-12.

[5] Jiniarti, B. E., Harjono, A., \& Makhrus, M. (2019). Pengembangan Perangkat Model Pembelajaran Berbasis Masalah Berbantuan Virtual Eksperimen Untuk Meningkatkan Penguasaan Konsep Peserta Didik Pada Materi Alat-Alat Optik. Jurnal Pijar Mipa, 14(2).

[6] Chodijah, S., Fauzi, A., \& Ratnawulan, R. (2012). Pengembangan Perangkat Pembelajaran Fisika Menggunakan Model Guided Inquiryyang Dilengkapi Penilaian Portofolio pada Materi Gerak Melingkar. Jurnal Penelitian Pembelajaran Fisika, 1(1).

[7] Susilawati, S., Jamaluddin, J., \& Bachtiar, I. (2017). Pengaruh Model Pembelajaran Berbasis Masalah (Pbm) Berbantuan Multimedia Terhadap Kemampuan Berpikir Kritis Peserta Didik Kelas Vii SMP Negeri 2 Mataram Ditinjau Dari Kemampuan Akademik. Jurnal Pijar Mipa, 12(2), 64-70.

[8] Sofyan, H., \& Komariah, K. (2016). Pembelajaran problem based learning dalam implementasi kurikulum 2013 Di SMK. Jurnal Pendidikan Vokasi,6(3), 260271.

[9] Rahayu, R., \& FX, E. W. L. (2015). Pengembangan Perangkat Pembelajaran IPA berbasis Problem Based Learning di SMP. Jurnal Kependidikan: Penelitian Inovasi Pembelajaran, 45(1).

[10] Setyorini, U., Sukiswo, S. E., \& Subali, B. (2011). Penerapan model problem based learning untuk meningkatkan kemampuan berpikir kritis siswa SMP. Jurnal Pendidikan Fisika Indonesia, 7(1).

[11] Gall, M. D., Borg, W. R., \& Gall, J. P. (1996). Educational research: An introduction. Longman Publishing.

[12] Punaji, S. (2010). Metode penelitian pendidikan dan pengembangan. Jakarta: kencana.

[13] Atmojo, S. E. (2013). Penerapaan Model Pembelajaran Berbasis Masalah dalam
Peningkatan Hasil Belajar Pengelolaan Lingkungan. Jurnal Kependidikan: Penelitian Inovasi Pembelajaran, 43(2).

[14] Setiyorini, N. D. (2018). Pembelajaran Kontekstual Ipa Melalui Outdoor Learning Di Sd Alam Ar-Ridho Semarang. journal ALMUDARRIS, 1(1), 30-38.

[15] Suryani, E., Jekti, D. S. D., \& Ramdani, A. (2015). Pengembangan Perangkat Pembelajaran Model Belajar di Lingkungan (Outdoor Learning) untuk Mata Kuliah Morfologi Tumbuhan. Jurnal Penelitian Pendidikan IPA, 1(2).

[16] Widoyoko, E. P. (2009). Evaluasi program pembelajaran (Vol. 91). Yogyakarta: Pustaka Pelajar.

[17] Listyawati, M. (2012). Pengembangan perangkat pembelajaran IPA Terpadu di SMP. Journal of Innovative Science Education, 1(1). 